\title{
Europas historie
}

\section{Thorsten Borring Olesen}

\section{Politik, økonomi og kultur blandes til en stor for- tælling om Europas genrejsning fra asken}

Tony Judt: Postwar. A History of Europe since 1945. (Penguin 2005) Pimlico 2007, 933 sider.

'Awesome' er et gennemgående udtryk brugt i de angelsaksiske anmeldelser af den britisk-fødte, men i New York bosiddende historiker Tony Judts bog om efterkrigstidens Europa. Man kan også roligt fastslå, at bogens 933 tættrykte sider indeholder mere stof, end man lige pløjer sig igennem på et weekendophold i sommerhuset. Men det respektindbydende ved bogen ligger ikke kun i dens monumentale størrelse. Det består i mindst lige så høj grad i bogens indholdsmæssige kvaliteter. Det er således beundringsværdigt, at Judt i den grad formår at skrive bred samfundshistorie, hvor politik, økonomi og kultur - Judt er eksempelvis særdeles velbevandret $\mathrm{i}$ både europæisk litteratur og film blandes sammen til en stor fortælling om Europas genrejsning fra asken siden 1945. Og vel at mærke en fortælling, som tager lige så me- get afsæt i Øst som i Vest i forsøget på at præsentere en samlet syntese om Europas udvikling fra Anden Verdenskrigs afslutning til i dag.

Når projektet lykkes hænger det sammen med, at Judt har samlet sin fremstilling omkring fem gennemgående temaer eller 'master tales'. Den første handler om Europas 'decline'. Det er den velkendte historie om, hvordan Europa efter Anden Verdenskrig uigenkaldeligt havde mistet positionen som verdens politiske, økonomiske og kulturelle (magt)centrum. Politisk blev Europa skåret over i en Vest- og Østdel, der blev gjort til satellitter i de nye supermagters imperier, Pax Americana og Pax Sovjetica.

Selv om dette forhold allerede stod lysende klart i den første efterkrigstid har Judt en pointe, når han hævder, at året 1956 kan karakteriseres som det endegyldige symbolske udtryk for Europas deroute. I Øst blev pointen drevet hjem, da sovjetiske tanks knuste den ungarske opstand, hvor den virkelige helligbrø- 


\section{LITTERATUR}

de ifølge Judt ikke bestod i eksperimenter med markedsøkonomi eller forsøget på at løsne båndene til Warszawa-pagten, men derimod i at opstanden udgjorde en trussel mod det kommunistiske partis dominerende position i ungarsk politik. Det var nemlig kontrollen med kommunistpartierne, der udgjorde kerneelementet i sikringen af Sovjet-regimets interesser i Østeuropa.

Næsten samtidig måtte Storbritannien og Frankrig stå skoleret for USA for deres militære ekspedition til Suez-kanalen. Operationen var iscenesat som en fredsskabelsesintervention, selv om det var de to tidligere stormagter selv, som havde aftalt med Israel at angribe Egypten, da landets nye stærke mand general Nasser nationaliserede Suez-kanalen. Sådanne eventyr var ikke velsete i Washington, som på ret ydmygende vis belærte de to landes regeringer om, at nok var man allierede, men dirigentstokken blev svunget på den anden side af Atlanten.

Overordnet set viste episoden også tydeligt, at Europa ikke længere var i stand til at sætte dagsordenen uden for Europa. De tidligere kolonier løsrev sig, og når moderlandet, ikke mindst Frankrig, fors $ø$ te at forhindre frigørelsen, ledte det til krig med efterfølgende nederlag. Kampen om Algeriet tog endda livet af det politiske system i Frankrig i 1958 og førte til dannelsen af en ny Femte Republik under præsident de Gaulles magtfulde ledelse.

\section{Hvad udad tabes}

Recepten, hvad udad tabes må indad vindes, er velkendt i Danmark, men der udgør også kernen i Judts anden og tredje 'master tale'. Det er Judts pointe, at den store politiskideologiske kamp mellem Højre og Venstre og mellem radikale fløjgrupper og demokrater, som havde præget europæisk politik i det 19. og første del af det 20. årh., gav efter for en meget mere konsensusorienteret politik. Denne fandt udtryk i opbakningen til (i Vest) socialdemokratiske og kristelige demokratiske partier, der trods variationer langt hen var forenet i målsætningen om at supplere det parlamentariske demokrati med en social dimension, eller kort og godt at opbygge en moderne demokratisk velfærdsstat. Selv i Øst fandt velfærdsideologien et vist nedslag, selv om eksperimentet her, især på grund af stigende økonomiske strukturproblemer for de socialistiske økonomier, ikke faldt helt så heldigt ud.

Det var naturligvis ikke kun økonomiske problemer, men også Sovjetunionens politiske kontrol og hårdhændende indgriben i de politisk-økonomiske forhold. der underminerede forsøgene på at skabe moderne velfærdsstater i Østeuropa. Det er således Judts tolkning, at ideologiseringen af europæisk politik oplevede en opblomstring i 1960'erne. I Øst endte denne opblomstring imidlertid, da Warszawapagt- 
styrker i 1968 kvalte Prag-foråret. Ifølge Judt betød denne begivenhed, at alle illusioner om forandringer indefra med henblik på at skabe et reform-socialistisk system blev endegyldigt stedt til hvile.

Også i Vest betegnede 1968 en kulmination på et kortvarigt forsøg på at reideologisere politikken. Denne reideologisering var del af ungdomsoprøret, som bl.a. blev næret ved et ubehag ved velfærdsstaten. Men ifølge Judt rystede Det Nye Venstre ikke velfærdsstaten, for med indgangen til 1970'erne havde reideologiseringen allerede toppet og fandt i tiden fremover kun udtryk inden for de alleryderste politiske fløje. Et af disse udtryk var 1970'ernes terrorbølge, som hærgede en række større europæiske lande, men selv disse væbnede forsøg på at destabilisere staten formåede ifølge Judt ikke for alvor at rokke systemet.

Selv om sidstnæunte perspektiv i en historisk betragtning givet er holdbart, vil de fleste, der har oplevet denne periode, fx i Vesttyskland og Italien, erindre sig, at terrorfænomenet påvirkede politik og kultur nok så meget. Spørgsmålet er, om Judt på dette punkt ikke bliver offer for sin egen overordnede ambition om at ville sammenskrive $\emptyset$ st-historien og Vest-historien. Hvor der er meget gehalt i tolkningen af, at 1968 i Øst betød enden for reformsocialisme-ambitionerne, virker det som om, at Judt for tidligt tager livet af 1968 i Vest. Når man ser på styr- ken af Det Nye Venstre og udbredelsen af den alternative ungdomskultur gennem det næste tiår, er der jo meget, der taler for, at de virkelige 60 'ere lå i 70'erne.

\section{Tredje Industrielle Revolution}

Årsagen til at Judt har så travlt med at få afviklet 1968 skyldes, at man i 1970'erne ser en anden og nok så stærk trussel mod velfærdsstaten og det tankegods, der har næret den, bryde frem. I 1970'erne ophørte nemlig den lange højvækst-konjunktur, som velfærdsstaten var blevet opbygget under. Nedbruddet for Bretton Woods-systemet, der havde reguleret det internationale monetære system med dollaren som det solide ankerfæste, og oliekriserne kastede økonomierne i Vest ud i en decideret lavkonjunktur præget af stagnation og lavvækst, høj inflation og stor arbejdsløshed - en udvikling som lagde stærkt pres på velfærdsstaten og den keynesianske økonomiske tænkning bag den.

Problemerne blev forstærket af, at de tårnede sig op netop i take-off fasen for det, man kalder Den Tredje Industrielle Revolution, hvor dynamikken i den kapitalistiske verdensøkonomi forskød sig mod informationsteknologiens fagre verden. I den proces var Europa ikke i førertrøjen, og hvor man i 1950'erne og 60'erne havde talt om det europæiske Wirtschaftswunder, talte man i 1980'erne om den udbredte eurosclerose. Judt 


\section{LITTERATUR}

viser imidlertid, at Øst-økonomierne ligeledes blev ramt af krisen, og at krisen her udviklede sig til at blive permanent på en cocktail af stigende gældssætning, forældede produktionsteknikker og en fuldstændig afkobling fra det nye informationsteknologiske gennembrud - en udvikling, der er væsentlig for at forstå det sammenbrud, som hele Østblokken inklusive Sovjetunionen oplevede i 1980'erne.

Så galt gik det ikke med den vesteuropæiske velfærdstat. Ganske vist skete der et økonomisk paradigmeskifte fra keynesiansk interventions$\varnothing$ konomi til et stærkere fokus på neoliberal udbudsøkonomi, ligesom der også fandt en politisk forskydning sted fra centrum-venstre regeringer til liberal-konservative regeringer. Men ændringerne skete gradvist, slog først for alvor igennem i 1980'erne og førte ikke til en afvikling af velfærdsstaten, kun til en trimning. Selv om der var neoliberale ideologer, der vejrer morgenluft, fastholdtes velfærdsstatsprojektet og med det også helt grundlæggende afideologiseringen af den vesteuropæiske politik.

Der var én undtagelse fra dette mønter - Storbritannien. Som Judt slår fast, "only in Britain was the political disciples of Hayek and Friedman able to seize control of public policy and wreck a radical transformation in the country's political culture" (Judt: 537). Årsagen ser Judt i det paradoksale faktum, at skønt
Storbritannien på mange måder ved Anden Verdenskrigs slutning var en pioner i opbygningen af den moderne velfærdsstat, så fik man aldrig afideologiseret projektet. Der blev ikke udviklet de korporative strukturer, som andre steder i Vesteuropa bidrog til at sammenbinde velfærdsstatsudvikling med arbejdsmarkedsstabilitet og tilpasningsevne, og som knyttede alle parter - stat, arbejdsgivere og fagbevægelse - til det fælles velfærdsprojekt.

I Storbritannien holdt fagbevægelsen fast i den traditionelle klassekampsmentalitet og den politiske ideologisering, og på det grundlag var det ekstremt vanskeligt at komme igennem med nødvendige reformer af den britiske økonomi, som i hele efterkrigstiden vækstmæssigt havde haltet efter den mere dynamiske udvikling på Kontinentet. Som Judt ser det, banede Thatchers hårdhændende og succesfyldte fremfærd mod den britiske fagbevægelse vejen for den fornyelse, der kurerede 'den britiske syge', men som han tilføjer var prisen, at Storbritannien "as a society suffered meltdown.” (Judt: 543)

\section{Den europæiske model}

Hvis velfærdstatspolitikken udgør det ene ben i den europæiske indre genrejsning, kan man sige, at den europæiske integrationsproces, eller som Judt benævner det, 'den europæiske model', udgør det andet - 
interdependente - ben. Historien om denne model fungerer som Judts tredje 'master tale'. Han har selv kondenseret denne fortælling på følgende markante vis: "Thirdly, and as a modest substitute for the defunct ambitions of Europe's ideological past, there emerged belatedly - and largely by accident the 'European model'. Born of an eclectic mix of Social Democratic and Christian Democratic legislation and the crab-like institutional extension of the European Community and its successor Union, this was a distinctively 'European' way of regulating social intercourse and inter-state relations. Embracing everything from child care to inter-state legal norms, this European approach stood for more than just the bureaucratic practices of the European Union and its member states; by the beginning of the twenty-first century it had become a beacon and example for aspirant EU members and a global challenge to the United States and the competing appeal of the "the American way of life'". (Judt: $7 \mathrm{f}$.)

Citatet her udgør en nøgle til den samlede bog, idet den i hvert fald knytter an til fire af de fem 'master tales', som Judt strukturerer bogen efter. Som citatet viser, er det Judts opfattelse, at Europas historie ikke længere kan fortælles som historien om Europas 'decline'. Gennem den europæiske model har Europa hentet ny identitet, nyt ståsted og ny styrke og er oven i købet i færd med at hele den splittelse i to halvdele, som var en realitet under den kolde krig. Det er i meget høj grad takket være denne models succes, at Judt overordnet konkluderer, at den næste samlede bog om Europas historie ikke kan sammenfattes under overskriften 'Efterkrigstid': Som han skriver som afslutning på bogens introduktion: "Postwar in Europe lasted a very long time, but it is finally coming to a close." (Judt: 10)

Det er lige så oplagt, at tolkningerne vedrørende den afideologiserede politik, betydningen af velfærdsstatsprojektet og naturligvis af den europæiske models fremvækst og triumf kan læses ud af citatet. Det er interessant at notere sig, at den vægt citatet lægger på, hvordan EU har stået som en rollemodel og magnet i den østeuropæiske transformations- og frigørelsesproces efter 1989 også følges op i bogens meget fine kapitler om disse processer. Hos befolkningerne i alle de østeuropæiske lande, der har søgt optagelse, har ønsket om tilknytning til EU stået stærkt, men som Judt viser ikke nødvendigvis som led i en reflekteret politisk analyse, som et middel til at sikre demokratiet eller på baggrund af en anti-russisk impuls, men ofte fordi EU i den brede befolknings øjne slet og ret repræsenterede et stærkt brand.

Denne tolkning knytter an til bogens fjerde 'master tale', der handler om Europas vitale, men blanden- 


\section{LITTERATUR}

de forhold til USA gennem hele efterkrigstiden. I Vesteuropa blev USA under den kolde krig både betragtet som sikkerhedsgarant og som gatecrasher, der ikke altid respekterede det finere suverænitetspil hverken i det bilaterale forhold, eller når det handlede om at organisere Vesteuropa. På samme vis på det kulturelle felt, hvor USA både repræsenterede den dynamiske fremtid og den åndløse kulturformørkelse. Dette mønster er ikke blevet mindre kompliceret eller dobbelttydigt efter koldkrigens ophør. Bush-administrationen har selv deltaget aktivt i spillet om Europas nye sjæl med sin destinktion mellem Old Europe og New Europe, som bl.a. har fundet resonans i det faktum, at det amerikanske brand i dele af Østeuropa (og Danmark?) har stået lige så stærkt som det europæiske.

Judts tolkning er imidlertid klar. Med særlig reference til holdningen i Østeuropa slår han fast: "For a long time America had been another time - Europe's future. Now it was just another place" (Judt: 790). Det er flot formuleret, og det er givetvis også langt hen rigtigt. Men man kan ved læsningen af den afsluttende diagnose af nutidens amerikansk-europæiske forhold ikke rigtigt frigøre sig fra den tanke, at Judt har en tendens til at gøre den europæiske model stærkere, end den i virkeligheden er, og til at undervurdere den fortsatte vigtighed for $\mathrm{Eu}$ ropa af et godt forhold til USA. En af de største udfordringer for den europæiske model i fremtiden kan nemt tænkes at ligge i, hvorvidt det lykkes at skabe en fælles og bæredygtig europæisk platform for håndteringen af forholdet til USA.

\section{Den historiske arv}

Tolkningen af, at Europa er ved at bevæge sig ud af efterkrigstiden, skyldes imidlertid ikke kun den europæiske models succes. Den skyldes også, at Europa og europæerne i dag tør konfrontere sig åbent med den europæiske historie og ikke mindst med dens virkelig mørke kapitler fra perioden 1914-1945. Her finder vi Judts femte og sidste 'master tale'. Den er organisk integreret i bogens kapitler, men vies også særlig opmærksomhed i den afsluttende epilog med titlen, "From the House of the Dead. An Essay of Modern European Memory". Her er det altså den historiske arv fra perioden før efterkrigstiden, den private og kollektive erindring om denne, og historien om hvordan samspillet mellem arv og erindring har påvirket europæisk politik i efterkrigstiden, der står i centrum

Betydningen af dette felt sammenfatter Judt indledningsvis på følgende måde: "World War One destroyed old Europe; World War Two created the conditions for a new Europe. But the whole of Europe lived for many decades after 1945 in the long shadow cast by the dictators 
and wars in its immediate past." (Judt: 6). Den mest markante, men også kontroversielle arv fra mellemkrigstiden er ifølge bogen de ugerninger i form af krig, etnisk udrensning og folkemord, som blev udført på Hitlers og Stalins ordrer.

Disse ugerninger skabte et dybt sår i europæisk civilisation og selvforståelse, men hører ifølge Judt også med til baggrunden for den europæiske succeshistorie efter 1945. De forbryderiske løsninger i perioden 1914-1945 fjernede ganske enkelte en række af de nationale og etniske modsætninger, som var en konstant bombe under mellemkrigstidens politik og var dermed også en afgørende forudsætning for afideologiseringen og succesen med at opbygge homogene national- og velfærdsstater i efterkrigstiden. Med en brutal logik kan Judt henvise til, hvordan det faktisk er gået i det eksjugoslaviske område, som trods åbenbare etniske spændinger aldrig blev religiøst og etnisk homogeniseret i før-efterkrigstiden.

I forlængelse heraf påpeger Judt at det har været en fordel for Europa, at der i den første efterkrigstid generelt blev lagt låg på debatten om de europæiske forbrydelser og skyldsspørgsmålet i relation hertil. I den første efterkrigstid var der naturligvis en tendens til at give Hitler og Tyskland skyld for det onde i Europa.

Men selv sejrherrerne opgav hurtigt afnazificeringspolitikken i Vest- tyskland, og blandt vesttyskerne selv var det først for alvor med ungdomsoprøret, at den tyske historie og især Nazi-tidens forbrydelser blev genstand for nogen større selvransagelse - og vedrørende Stalins forbrydelser skete det først ved afslutningen af den kolde krig. Judt er ganske usentimental, når han slår fast, at glemslen og fortielsen havde den fordel, at den tillod europæerne at fokusere på fremtiden uden at hænge i fortiden og især uden at lade konflikter om fortidens skyldsspørgsmål forpeste opbygningen af et nyt Europa. I den forstand have europæerne lært noget siden Første Verdenskrig.

Judt er imidlertid så meget inde i emnet om erindring og erindringspolitik, at han ved, at den slags nationale traumer ikke kan holdes nede i evighed. Derfor opfatter han det som sundt, at der i dag er langt større bevidsthed om de betændte sider af den europæiske historie, som også kan være en nyttig lære i en tidsalder, hvor Europa i stigende grad igen er ved at blive multikulturaliseret - og måske som følge heraf også reideologiseret. Men pointen er, at Europa i dag er meget bedre rustet til at se sin egen fortid i øjnene, end det eksempelvis var i 1950'erne. For Judt er det et sundhedstegn, at man i dag kan diskutere spørgsmålet om Allierede krigsforbrydelser under Anden Verdenskrig (fx bombningen af Dresden og sænkningen af tyske flygtningeskibe). 


\section{LITTERATUR}

\section{Hug en hæl og klip en tå}

At skrive en bred Europa-historie, som Judt gør, kræver et enormt overblik og voldsom arbejdsindsats. Det kan heller ikke undgås, at der bliver klippet en tå og hugget en hæl rundt omkring for at få pengene til at passe. Eksempelvis vil jeg påstå, at man ikke bliver så voldsom klog på dansk/nordisk historie ved at læse bogen - kun indirekte hvis man selv evner at relatere den nordiske erfaring til Judts master tales. For Danmarks vedkommende optræder landet mest markant i forhold til diskussionerne af velfærdsstaten, EU-modstand og fremmedfjendskhed. Men problemet er også, at på nogle områder passer Danmark/Norden ikke ind i, ja modsiger snarere mesterfortællingerne, ikke mindst den anden og tredje fortælling.

Problemet ligger ikke så meget $\mathrm{i}$ den indholdsmæssige beskrivelse af-ideologiseringen og velfærdstatsideologien var bestemt også markante post-1945 fænomener i Norden men snarere i spørgsmålet om timing og linkning mellem fortælling 2 og 3. Det er som vist Judts tolkning, at Europa oplevede et brud og ny begyndelse i 1945 . Ser man på Norden, både på spørgsmålet om afideologisering og velfærdstatstopbygningen, giver det imidlertid mere mening at se 1945 som en tilbagevending til en kurs, der allerede var slået markant igennem i mel- lemkrigstiden. Dette er måske hovedårsagen til, at mellemkrigstidens autoritære bevægelser aldrig for alvor slog igennem i Norden.

Denne forskel er vigtig, især fordi den havde store konsekvenser for nordisk politik i efterkrigstiden. Når Judt i sin fortælling kan placere udviklingen af den europæiske model (fortælling 3) som liggende i logisk forlængelse af fortælling 2 (opbygningen af den moderne demokratiske velfærdstat), så kan denne forbindelse ikke etableres på samme overbevisende måde i relation til Norden, hvor den europæiske model ofte er blevet opfattet som en trussel mod den nordiske velfærdsstat. Har man ikke fat i denne anderledeshed, kan man heller ikke overbevisende forklare den vanskelighed, de nordiske lande har haft ved at omfavne det europæiske projekt.

Denne forsømmelse skal ikke lægges Judt voldsom til last. Historien om Europa er jo i høj grad også historien om diversitet og heterogenitet, som man være svær at indfange i al sin detaljerigdom i en bog, som har synteseambitioner. Judt har lagt en både nuanceret og fascinerende tolkning af den europæiske efterkrigstid for os. Bolden er givet op til, at nationale historikere i alle Europas verdenshjørner kan gå i kritisk dialog med bogen.

Thorsten Borring Olesen er professor ved Institut for Historie og Områdestudier, Aarhus Universitet. 